\title{
Evaluation of the loss of assimilation apparatus and its causes in Scots pine stands (Pinus sylvestris L.) of the Kampinos National Park
}

\author{
Eukasz Tyburski $\bowtie$, Pawet Przybylski ${ }^{2}$ \\ ${ }^{1}$ Kampinos National Park, Department of Science and Nature Monitoring, Tetmajera 38, 05-080 Izabelin, Poland, \\ email: ltyburski@kampinoski-pn.gov.pl \\ ${ }^{2}$ Forest Research Institute, Department of Silviculture and Genetics of Forest Trees, Braci Leśnej 3, Sękocin Stary, \\ 05-090 Raszyn, Poland
}

\begin{abstract}
The Kampinos National Park (KNP), in terms of ecology, is an exceptionally valuable place in the Polish lowland region. Until the 20th century, as a result of limited human influence on the natural resources of the Kampinos Forest, it can be presumed that the 100-year-old tree stands were shaped by natural ecological processes. This study contains a detailed assessment of crown conditions, dendrometric measurements and visible disease symptoms in the oldest fragments of the KNP, as well as statistical evaluation of the relationships between these factors. Results were correlated with ecological factors such as precipitation and temperature.

For the purpose of the study, five tree stands, each over 130 years old, were selected. In each stand, the level of defoliation was assessed, based on the forest monitoring methodology performed in Poland for the State Environmental Monitoring. Tree height, circumference, and diameter at breast height measurements were performed for all the trees, and any visible disease symptoms were described.

Defoliation data were used to classify $93.6 \%$ of the trees as the second level of stand damage (the so-called 'warning' level) according to the monitoring methodology. Observed disease factors confirm the physiological weakening of the trees. The populations studied exhibited a range of mean height and stem volume, and these were not significantly related to the level of defoliation or visible disease symptoms. Ecological factors, especially the drought in 2015, probably did not have a negative impact on the examined stands.

The analysed pine populations demonstrate physiological weakness, but this appears to be related to their age and natural ecological processes.
\end{abstract}

\section{KEY WORDS}

Defoliation, health condition, Kampinos Forest, old trees 


\section{INTRODUCTION}

The Kampinos National Park (KNP), established on 16 January 1959, is a unique and valuable place in the Polish lowland region. Its dune belts and marshy lands, resulting from the presence of a complex of inland dunes, contribute to the preservation of the mosaic environment (Zgorzelski and Pawłowska 2003). The area contains rare plants (Głowacki and Ferchmin 2003), fungi (Karasiński et al. 2015; Gierczyk et al. 2017), birds (Pepłowska-Marczak 2018) and invertebrates (Marczak 2010; Marczak and Masiarz 2013). Due to the topography and location of this area, numerous species use it as a refuge. The structure of old-forest trees on inland dunes found in the park is virtually unheard of elsewhere in Europe.

Until the 18th century, stand structure in the Kampinos Forest had not been significantly influenced by humans. Historically, the easily accessible areas were used, such as those in the southern part (Heymanowski 1969a). The remaining stands were left to nature due to low accessibility. However, since the 18th century, the development of mid-forest settlements occurred, providing evidence of the early use of the Kampinos Forest (Heymanowski 1969b). Unfortunately, as a result of World War I and II and later afforestation works (Zielony 2004), humans had a significant influence on the species composition and age structure of the Kampinos forests. Today, in the KNP, the dominant tree species are Scots pine (69\%) and black alder (12.5\%) (Szczygielski 2002). It was not until the establishment of reserves (the oldest, Zamczysko, in 1924) and the subsequent creation of the national park that human influence within the Kampinos Forest was reduced. It should, however, be assumed that the total area occupied by the old-growth native pine trees (over the age of 100 years) in KNP is about 6,000 ha (Tyburski 2015).

This study attempted to increase the knowledge about a set of focal tree stands in KNP due to the uniqueness and potential nativeness of the tree stands. This work was carried out as a part of the project ' $\mathrm{Ge}$ netic Characterization of Scots Pine Stands (Pinus sylvestris) in the Kampinos National Park - Stage I', which includes an assessment of the loss of assimilation apparatus and its causes, as well as the height and diameter at breast height (dbh) of the examined trees.
Crown health assessment is used in monitoring the programs implemented in Poland and around the world (Dmyterko 1992; Jaszczak 1995; Lech 1995a). These assessments use the defoliation criterion as one of the elements of the assessment of forest health (Lech 1995b). In Poland, the data on defoliation are used, among others, in the assessment of forests' damage (Wawrzoniak 2015). The loss of the assimilation apparatus is one of the outcomes of the complex impact of drought (Lehner et al. 2006), which can activate parasitic fungi in the tree crowns, causing their browning and dying. The tree manifests this through the increased loss of the assimilation apparatus. In Poland, complex impacts of drought were reported in 2015 (Orphan and Novik unpublished data); the Climatic Water Balance (July-September) recorded by the Institute of Meteorology and Water Management for the KNP area showed a difference between water gains and losses in the evaporation process of minus 190-199 mm. The water deficit in the KNP in 2015 was confirmed by the detailed measurement data (Fig. 9). The weakening of the tree stands does not end with the disappearance of the complex impacts of drought, but instead a secondary weakening of the health condition of the trees is to be expected (Lehner et al. 2006).

The main measurement and observation objectives for this study were:

- an assessment of the status of crowns for the examined trees

- measurement of height and diameter of the examined trees

- a description of any visible disease symptoms of the examined trees

- a list of detailed meteorological data including precipitation and temperature at KNP

The following research hypotheses guided this work:

- Populations with higher defoliation are characterized by lower height and smaller diameter at breast height.

- A higher degree of defoliation is associated with observed disease symptoms. 
Table 1. Approximate age, type of forest habitat, and mean height and diameter at breast height of the examined stands

\begin{tabular}{|l|c|c|l|c|c|}
\hline \multicolumn{1}{|c|}{ Stand } & $\begin{array}{c}\text { Abbre- } \\
\text { viation }\end{array}$ & Age & \multicolumn{1}{|c|}{ Type of forest habitat } & Mean height & $\begin{array}{c}\text { Mean diameter } \\
\text { at breast height }\end{array}$ \\
\hline Czerwińskie Góry & $\mathrm{Cg}$ & $199-204$ & Mesic mixed coniferous & 28.8 & 58.9 \\
\hline Granica & $\mathrm{Gr}$ & $146-159$ & Mesic mixed coniferous /Fresh mixed forest & 30.6 & 64.3 \\
\hline Sieraków & $\mathrm{Si}$ & $189-199$ & Mesic coniferous/ Fresh mixed forest & 22.8 & 54.9 \\
\hline Wiersze & $\mathrm{Wr}$ & $144-164$ & Mesic coniferous & 27.3 & 48.4 \\
\hline Wilków & $\mathrm{Wi}$ & $181-201$ & Mesic coniferous & 28.5 & 61.5 \\
\hline
\end{tabular}

\section{StUdY AREA}

The research was carried out in five sites (Fig. 1) containing the old-growth Scots pine (over 130 years old) (Tab. 1). All the sites are located in areas protected by law.

The research sites were selected in a way that takes into account the diversity of the oldest stands and the entire area of the Park (Fig. 1). The age of the stand is calculated from estimates provided by the Forest Ecosystems Protection Service KNP as of 2001 (Tab. 1).

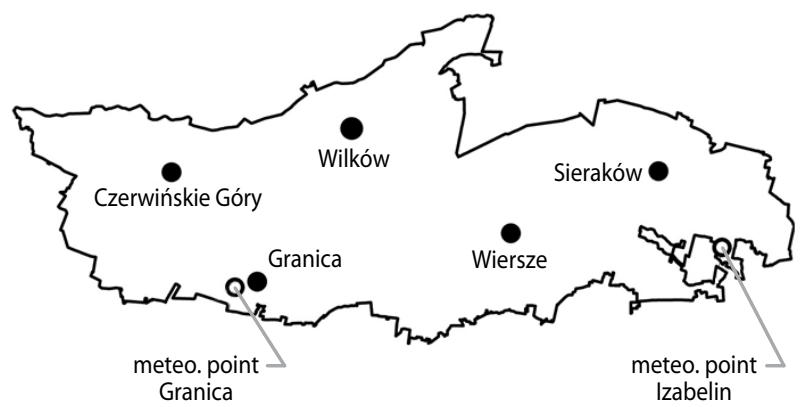

Figure 1. Map of the distribution of research areas and meteorological measurement stations in the Kampinos National Park

\section{Material AND Methods}

Fifty trees were selected in each studied tree stand, and a map was created using a handheld GPS unit with GIS software, which indicated the approximate location of the selected trees (Fig. 2-6). The distance between the trees was equal to at least one height of the stand. Each tree was marked on the landscape.

In the study sites, a health assessment of the crowns of all trees was performed. The assessment was carried out by adapting the forest monitoring methodology that is performed as part of the State Environmental Moni- toring. The methodology is presented in detail in the work of Tyburski and Przybylski (2016).

Dendrometric measurements (height, DBH) were carried out. Height measurement was performed using a Vertex diameter ultrasonic height meter (with an accuracy of $0.5 \mathrm{~m}$ ). Estimates of the DBH were made with the means of DBH of $1.30 \mathrm{~m}$ (to an accuracy of $1 \mathrm{~mm}$ ).

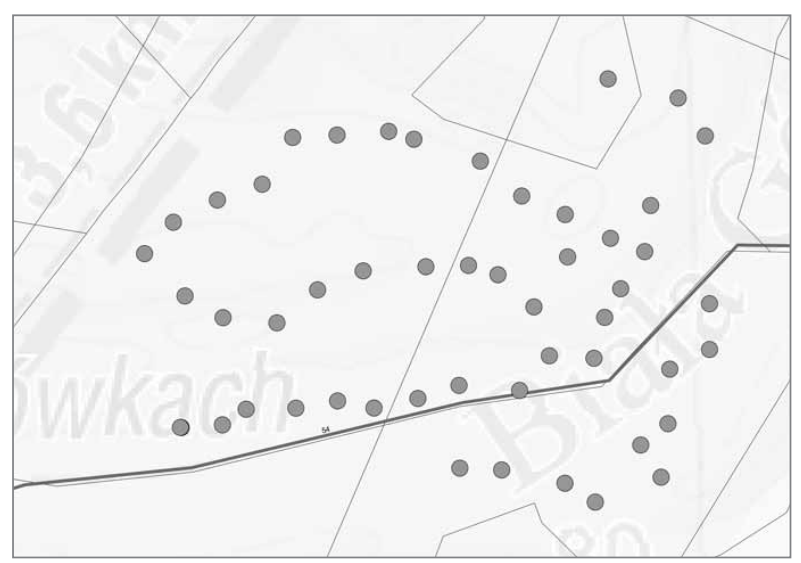

Figure 2. Distribution of trees in the Sieraków site

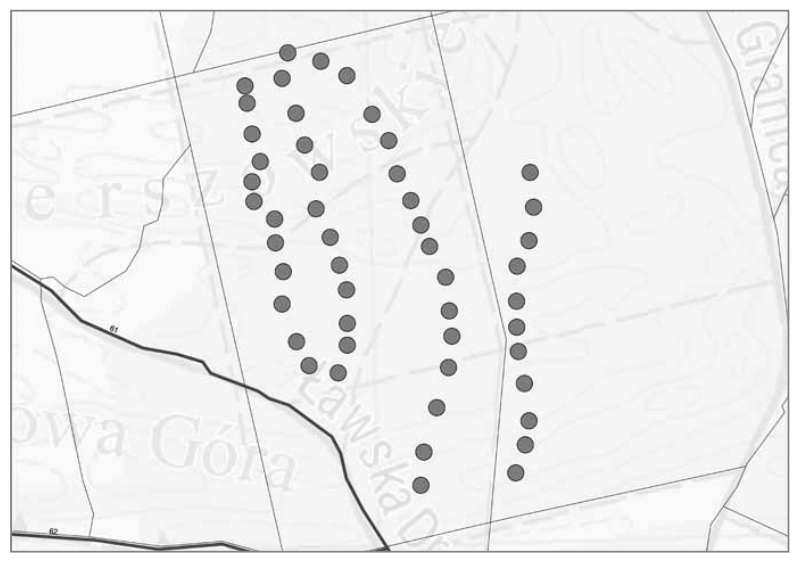

Figure 3. Distribution of trees in the Wiersze site 


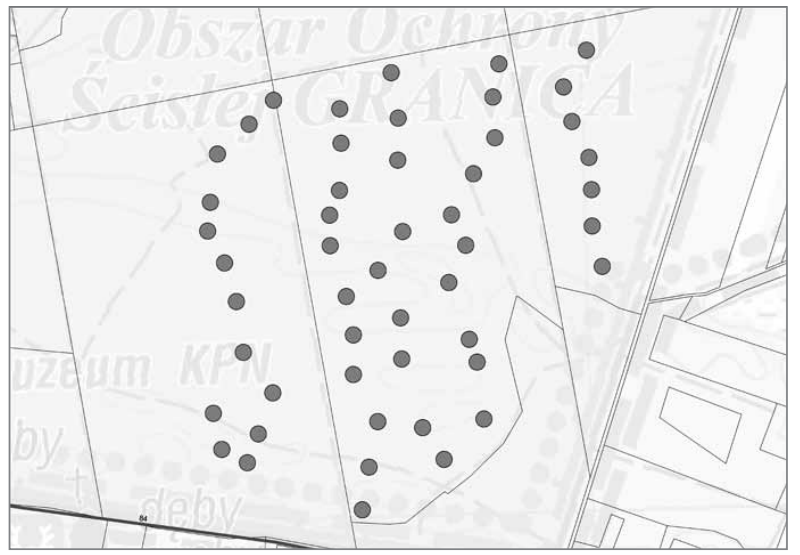

Figure 4. Distribution of trees in the Granica site

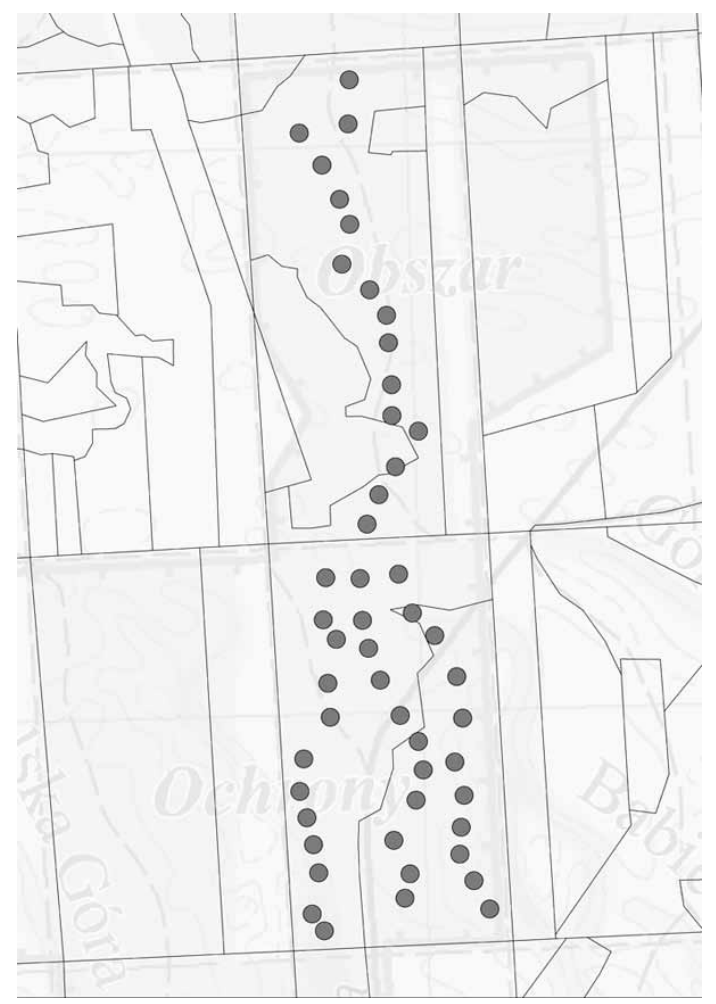

Figure 5. Distribution of trees in the Wilków site

Visual assessment of disease symptoms was made for all the examined trees and divided into three types: mistletoe, bracket fungus, and resin spills. The number of infected trees in each category was assessed for each study site.

Meteorological data from 2008-2017 were averaged from the measurement stations located in the KNP (Fig. 1), which provided total rainfall and average temperature.

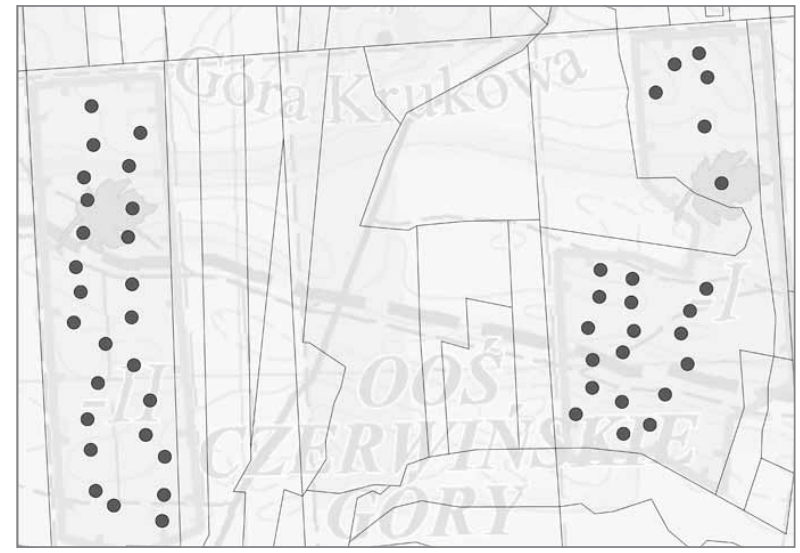

Figure 6. Distribution of trees in the Czerwińskie Góry site

Results were analysed statistically in accordance with the methodology described in detail by Tyburski and Przybylski (2016). Results were visualized in twodimensional graphs, where vertical bars indicate confidence intervals of 0.95 . Significant differences were assumed for those bars for which the confidence interval did not have convergent points.

\section{Results}

Aggregate health data for tree crowns on all the study sites is shown in Table 2. The data show that of the 250 examined trees, 234 (93.6\%) were classified as the second class of crown damage, that is, the warning class (Jaszczak 1999). Eleven trees (4.4\%) were classified as the first class. However, five trees (2\%) were classified as the third class. It is worth noting that in the (Gr) site, no tree was assigned to the first class of crown damage, while in the Czerwińskie Mountains ( $\mathrm{Cg}$ ) and Wiersze (Wr). Gr. sites, trees were classified as the third class.

Thinning type (centrifugal vs. thinning) was also described for each tree. A total of 149 trees (59.6\%) demonstrated thinning-type thinning, with the largest number of trees with this type of thinning (44 individuals) described in the Gr site. Centrifugal-type thinning was described only for 2 individuals $(0.8 \%)$, located in the Sieraków (Si) site.

Most trees - $141(56.4 \%)$ - had two suits of annual needles, whereas for 23 trees $(9.2 \%)$, three suits of annual needle studs were found; the largest concentration of these trees occurred in the Wi site (9 individuals). For 
86 individuals, one suit of annual needles was recorded. The largest number of individuals with one suit of needles was recorded on the Gr site (29 individuals).

Table 2. Thinning of crowns divided into defoliation classes, and the number of observed annual needles with occurrence of dead branches in crowns for the examined trees

\begin{tabular}{|c|c|c|c|c|c|c|c|c|}
\hline \multirow{2}{*}{ 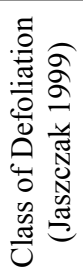 } & \multirow{2}{*}{$\begin{array}{l}\vec{E} \\
\text { 吾 } \\
\text { W }\end{array}$} & \multirow{2}{*}{ 怤 } & \multicolumn{2}{|c|}{ Thinning } & \multicolumn{2}{|c|}{$\begin{array}{c}\text { The number } \\
\text { of annual } \\
\text { needles }\end{array}$} & \multicolumn{2}{|c|}{$\begin{array}{l}\text { Occurrence } \\
\text { of dead } \\
\text { branches }\end{array}$} \\
\hline & & & 芆 & $\begin{array}{l}\text { number } \\
\text { of trees }\end{array}$ & $\begin{array}{c}\text { an- } \\
\text { nual }\end{array}$ & $\begin{array}{l}\text { number } \\
\text { of trees }\end{array}$ & క్. & $\begin{array}{l}\text { number } \\
\text { of trees }\end{array}$ \\
\hline \multirow{6}{*}{1} & $\mathrm{Cg}$ & 1 & \multirow{6}{*}{$\begin{array}{l}n \\
0 \\
0 \\
0 \\
\tilde{n} \\
\tilde{\sigma} \\
0\end{array}$} & 13 & \multirow{6}{*}{1} & 16 & \multirow{6}{*}{ き } & 0 \\
\hline & Wi & 3 & & 22 & & 15 & & 0 \\
\hline & Gr & 0 & & 2 & & 29 & & 0 \\
\hline & $\mathrm{Wr}$ & 3 & & 13 & & 13 & & 0 \\
\hline & $\mathrm{Si}$ & 4 & & 18 & & 13 & & 0 \\
\hline & $\sum$ & 11 & & 68 & & 86 & & 0 \\
\hline \multirow{6}{*}{2} & $\mathrm{Cg}$ & 47 & \multirow{6}{*}{$\begin{array}{l}\overline{0} \\
\text { อे }\end{array}$} & 7 & \multirow{6}{*}{2} & 29 & \multirow{6}{*}{ 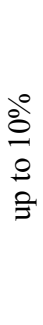 } & 37 \\
\hline & $\mathrm{Wi}$ & 47 & & 9 & & 28 & & 32 \\
\hline & Gr & 48 & & 4 & & 21 & & 47 \\
\hline & $\mathrm{Wr}$ & 46 & & 7 & & 28 & & 42 \\
\hline & $\mathrm{Si}$ & 46 & & 4 & & 35 & & 38 \\
\hline & $\sum$ & 234 & & 31 & & 141 & & 196 \\
\hline \multirow{6}{*}{3} & $\mathrm{Cg}$ & 2 & \multirow{6}{*}{ 寻 } & 30 & \multirow{6}{*}{3} & 5 & \multirow{6}{*}{$\begin{array}{l}0_{0}^{\circ} \\
\text { in } \\
1 \\
=\end{array}$} & 13 \\
\hline & Wi & 0 & & 19 & & 7 & & 18 \\
\hline & Gr & 2 & & 44 & & 0 & & 3 \\
\hline & $\mathrm{Wr}$ & 1 & & 30 & & 9 & & 8 \\
\hline & $\mathrm{Si}$ & 0 & & 26 & & 2 & & 12 \\
\hline & $\sum$ & 5 & & 149 & & 23 & & 54 \\
\hline
\end{tabular}

Occurrence of dead branches up to $10 \%$ was recorded for 196 trees $(78.4 \%)$, and the occurrence of dead branches in the range of $11-50 \%$ was recorded for 54 trees $(21.6 \%)$, with the highest density of such trees occurring in the Wi site (18 trees). No tree lacked dead branches.

Measured dendrometric data are presented in Table 1; they indicate that the average height of the examined trees was $27.6 \mathrm{~m}$, and the sites were characterized by a significant difference in mean heights (Fig. 7). The highest trees were found in the Gr stand, with a mean of $30.6 \mathrm{~m}$., and the lowest in the Si site, with a mean of $22.8 \mathrm{~m}$. The average DBH of trees in all the sites was 57.6 $\mathrm{cm}$. The largest diameters at breast height were recorded in the $\mathrm{Gr}$ site, with a mean of $64.3 \mathrm{~cm}$, and the smallest in the Wi site, with a mean of $48.4 \mathrm{~cm}$. The differences in diameters were statistically significant (Fig. 8).

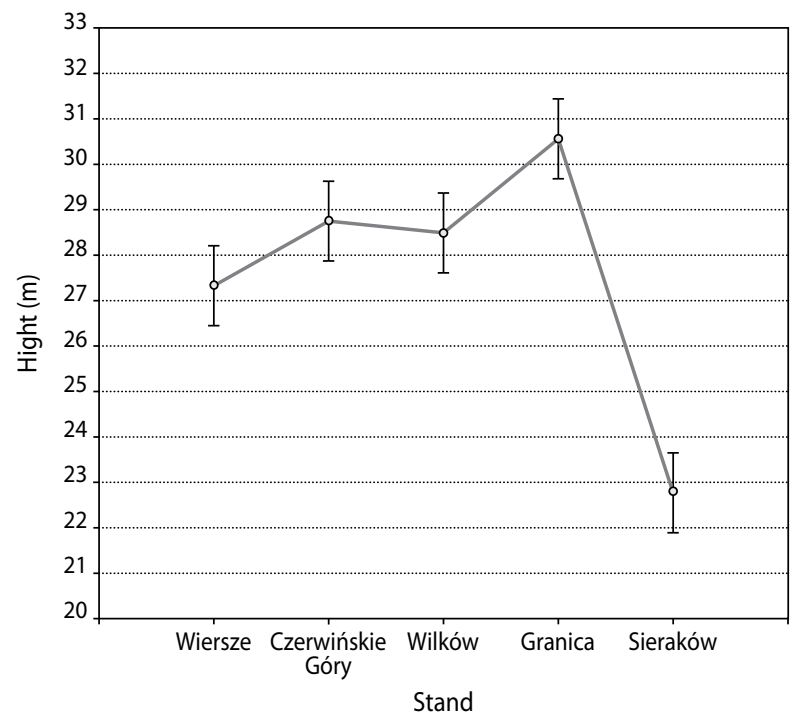

Figure 7. Comparison of average pine heights for the five research sites. Vertical bars represent confidence intervals of 0.95

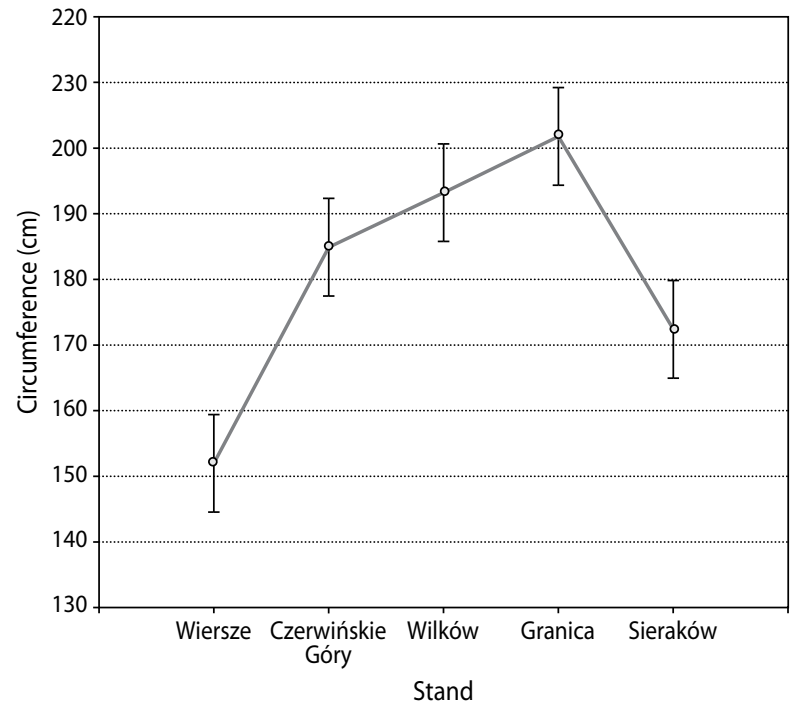

Figure 8. Comparison of medium pine circumferences for the five research sites. Vertical bars represent confidence intervals of 0.95 
Table 3. Observed disease symptoms and their occurrence by number and percentage of trees in the examined stands

\begin{tabular}{|l|c|c|c|c|c|c|}
\hline \multirow{2}{*}{$\begin{array}{c}\text { Type } \\
\text { of damage }\end{array}$} & \multicolumn{5}{|c|}{ Number and percentage of trees with observed disease features in the study sites } \\
\cline { 2 - 7 } & $\mathrm{Cg}$ & $\mathrm{Wi}$ & $\mathrm{Gr}$ & $\mathrm{Wr}$ & $\mathrm{Si}$ & $\Sigma$ \\
\hline Mistletoe & $23(46 \%)$ & $22(44 \%)$ & $14(28 \%)$ & $9(18 \%)$ & $15(30 \%)$ & $83(33.2 \%)$ \\
\hline Bracket fungus & $29(58 \%)$ & $23(46 \%)$ & $13(26 \%)$ & $18(36 \%)$ & $10(20 \%)$ & $93(37.2 \%)$ \\
\hline Resin spills & $13(26 \%)$ & $4(8 \%)$ & $2(4 \%)$ & $3(6 \%)$ & $6(12 \%)$ & $28(11.2 \%)$ \\
\hline
\end{tabular}

A detailed assessment of any external disease symptoms of the examined trees was carried out in the study sites, and the results are given in Table 3 . The most common stress factor detected for the trees was the bracket fungus, observed on $37.2 \%$ of analysed individuals. The most intensely infested population was in $\mathrm{Cg}$ site, where nearly $60 \%$ of the trees were damaged. The smallest number of pines $(20 \%)$ with annosum root rot basidiomata was observed in the $\mathrm{Si}$ site (Tab. 3).

Like bracket fungi, mistletoe was observed on the areas in the $\mathrm{Cg}$ population, which also coincides with the location of the observed resin spills. Sometimes all three forms of disease symptoms occurred on one tree, and the most frequent cases of this were observed in the Cg population.

Mean precipitation and temperatures are visualized in Figure 9. There was a significant decrease in average precipitation $(400 \mathrm{~mm})$ in 2015 , compared to the previous years $(2014 ; 615 \mathrm{~mm}$.). Additionally, in 2015 , the highest average temperature $\left(10^{\circ} \mathrm{C}\right)$ was recorded for the 10-year period of measurement. The years 2016-2017 were characterized by an increase in

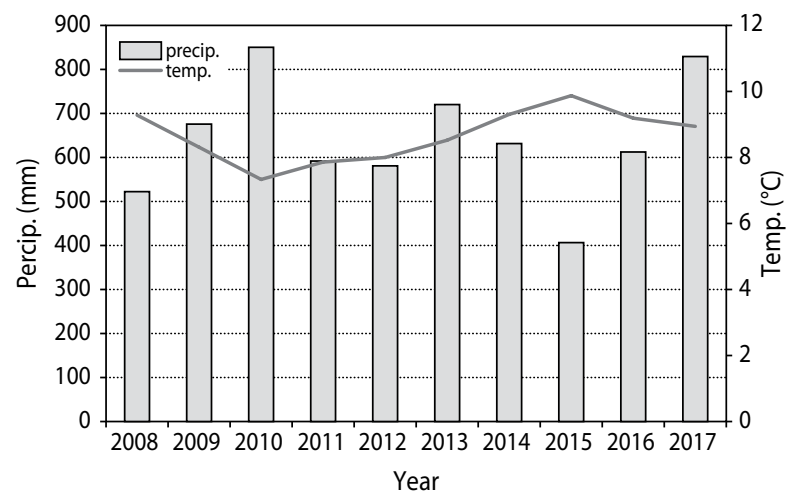

Figure 9. Average total precipitation and temperature from measurement stations located in Izabelin and Granica, from 2008-2017 (KNP data) the average amount of rainfall and a lower average temperature than 2015. It should also be noted that 2017 was characterized by a significant amount of precipitation (<800 mm), similar to 2010 .

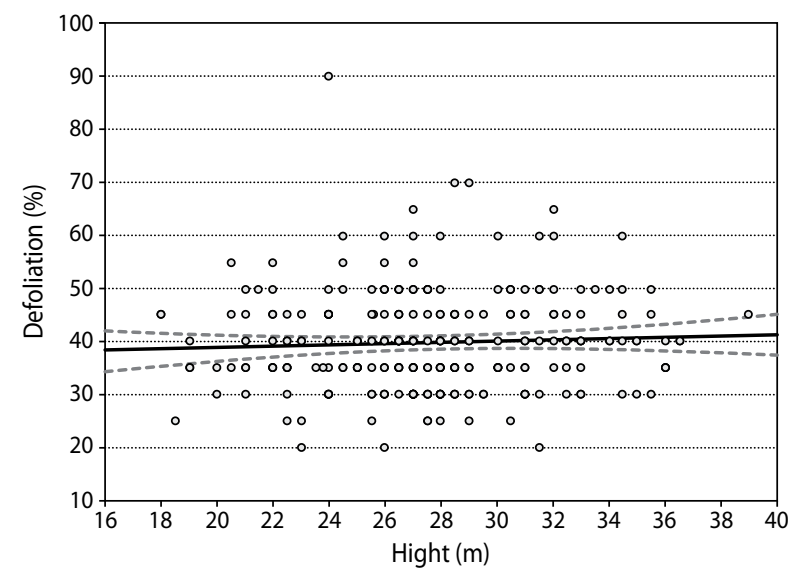

Figure 10. Correlation between the height $(\mathrm{m})$ of the examined trees and the level of their defoliation (\%) across all five research sites

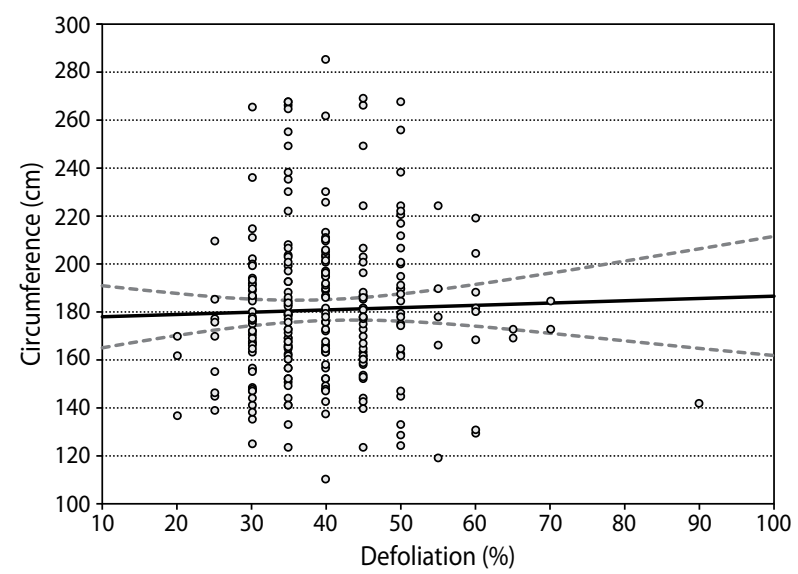

Figure 11. Correlation between the circumference $(\mathrm{cm})$ of the examined trees and the level of their defoliation (\%) across all five research sites 
The correlations ( $r$ ) between the height and diameter of the analysed trees and the level of their defoliation are presented in Fig. 10-11. There were no statistical relationships between the analysed parameters. The correlation coefficient for the relationship between height and defoliation was $r=0.05$, while the correlation coefficient for the relationship between diameter and defoliation was $r=0.03$. In addition, no relationship was found between the observed disease symptoms and the level of defoliation of the examined trees' crowns.

\section{Discussion AND CONClusions}

A detailed analysis of the health assessment found that the majority of trees $(93.6 \%)$ were in the second class of defoliation (26-60\%). According to the methodology, this is a warning state in which there is a clear inhibition of height increase, withering of the shoots in the apical part of the crown, low vitality of the trees, and dying of shoots in the central part of the crown (Jaszczak 1999). However, it should be borne in mind that the applied methodology was mainly developed for commercial stands which only sporadically occur in the old-forest phase. In addition, it is believed that the pine is a species in which practically no individuals are recorded with defoliation below $10 \%$. This is confirmed by the research done by Borecki et al. (1991).

In this study, there was a significant difference in defoliation between the Gr site and other research sites. The trees in the Gr site, compared to the remaining research sites, grow in the most fertile habitat (Szczygielski 2002). The largest DBH and tree height were also recorded in this sites. This suggests that with increasing habitat fertility, the analysed dendrometric values for Scots pine are higher. This relationship between the dendrometric parameters and habitat quality was demonstrated by Przybylski (1993), who stated that on rich soils, the Scots pine reaches the peak of productivity and the optimum of vitality earlier, and on poor habitats these peaks are delayed by several dozen years (Przybylski 1993). The results obtained in the KNP confirm these relationships (Fig. 12).

Regarding the thinning of the crown, $59.6 \%$ of trees were found to be affected, and $27.2 \%$ of trees

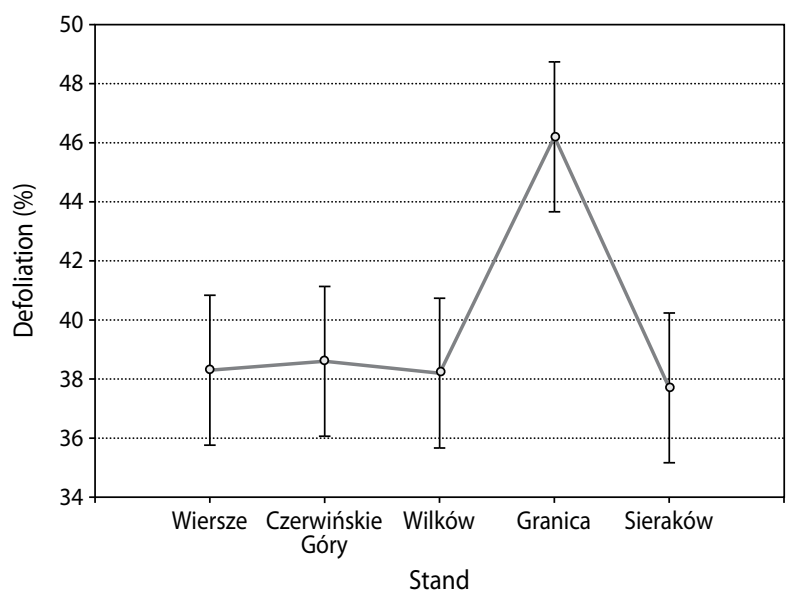

Figure 12. Comparison of the average defoliation index of pine crowns for the five research sites. Vertical bars represent confidence intervals of 0.95

were found to have grassroots thinning. In the case of pine, the typical type of thinning is grassroots thinning, which results from the slow loss of the assimilation apparatus associated with shading the lower branches of a tree. Old-growth trees naturally lose their ability to grow, and as a result of the death of individual trees, the density of trees gradually diminishes, because the lateral growth of crowns at this age is minimal (Szymański 2001).

Due to the natural weakness of trees resulting from old age, the most numerous annual needle class for the studied trees was a two-year suit of annual needles, at $56.4 \%$. For $34.4 \%$ of the trees, one year of annual needles was found, a signal of the commencement of the dying processes, which lasts for different amounts of time depending on the individual. Pine needles of normal lengths were observed for $99.2 \%$ of the trees. Based on this, it appeared that there was no disorder in the supply of nutrients. In the case of excess or deficiency, unusual needle growth may occur (hypertrophy or shortening). The occurrence of dead branches in $78.4 \%$ of the trees did not exceed $10 \%$. Scots pine is characterized by the dying of branches in the lower parts of the tree, which results from the known process of 'cleaning' the spire-shaped tree trunk, by eliminating the most shaded branches. Thus, these trees carrying 10\% dead branches were likely to be healthy.

The individuals assessed were severely affected by pathogens, as evidenced by the presence of the bracket fungi, resin spills and mistletoe. All the damage to the 
tree is indicative of weakness and physiological disturbances inside the trunk. Such disorders include decay processes caused by fungi. Porodaedalea pini (Brot.) Murrill, the cause of white speck pine decay causing the phenomenon of white pocket trunk rot, was found on the studied trees. Development of the disease in the studied stands is favoured by the presence of thick branches (Mańka 2005) subject to breaking and thus damage. These processes are a natural component of old age in trees. Damage of trees with diseases caused by fungi does not always indicate significant weakening of trees. Blajer and Beker (2015) found that in the case of a stand $74 \%$ infested by the annosum root rot, the pine stand showed only weak damage, if any. The results obtained here were consistent with those findings, and the relationship between paralysis fun bracket fungi and the defoliation index was not confirmed.

The KNP recorded significant variation in the average total precipitation and in temperatures over the time period 2008-2017. During the measurement period, there were years with an average rainfall of more than $800 \mathrm{~mm}$ (2010 and 2017), which caused local flooding of stands located in dunes and marsh belt lowlands. On the other hand, extremely low average rainfall amounts were recorded in 2015 (406.5 $\mathrm{mm})$, and during this period high temperatures also occurred. Low precipitation and high temperatures result in increased transpiration, which could lead to disturbances in pine physiology and the formation of complex impacts of drought (Lehner et al. 2006). At present, no significant weakening of the examined trees was observed that could have resulted from the strong variation in rainfall of recent years. It is assumed that the examined stands have a deep root system, which even in a period of prolonged drought covers the demand for water due to moist soil layers (Obmiński 1970). The strength of the trees, likely to be resulting largely from rainfall exceeding average for many years, is also bolstered by the fact that the examined stands are located in dune areas, where root damage - as a result of the increased level of subsurface waters - is lower than in depressions in a non-dune terrain. Pines demonstrate considerable tolerance for environmental factors such as atmospheric precipitation and thermal conditions (Przybylski 1993). On the other hand, changes in the level of rainfall in the last decade have had a negative effect on deciduous species in younger age classes. For example, in depressions of a non-dune terrain, alder death and weakening of oaks were observed (unpublished KNP data).

There is insufficient data in the literature concerning the relationship between defoliation and the height and DBH of trees. Studies on poplar showed a significantly smaller increase in height and trunk growth in trees when defoliation was in the range of $50-75 \%$ (Tucker et al. 2004). Lemke's studies found a strong correlation between the thickness of leafy branches and the volume increase of studied trees $(\mathrm{r}=0.802)$ (Jaworski 2004). A weaker correlation was found between the thickness of leafy branches and the tree diameter increase $(r=0.522)$. Height increase correlated significantly with the thickness of the leafy branches, but the correlation coefficient was small $(r=0.198)$ (Jaworski 2004). Studies have not confirmed the effect of loss of the assimilation apparatus on dendrometric indices and observed disease symptoms.

In conclusion, the health condition of the crowns of the examined pines places them in the warning class according to standard monitoring. On the other hand, taking into account the age of the analysed trees, specific terrain conditions and processes occurring naturally in old trees, the general condition of crowns should be considered compatible with naturally occurring ecological processes. However, the disease symptoms observed may indicate weakening of the examined pines and the approach of their terminal period. No clear relationship was observed between the defoliation index and disease factors and the dendrometric parameters of the examined old trees.

\section{ACKNOWLedgements}

The research was carried out as part of the task 'Genetic Characterization of Scots Pine (Pinus sylvestris) in the Kampinos National Park - Stage I', co-financed in 2017 by the Forest Fund PGL Lasy Państwowe.

\section{References}

Blajer, K., Beker, C. 2015. Zdrowotność wybranych drzewostanów sosnowych Nadleśnictwa Szczecinek. Zarzadzanie ochrona przyrody $w$ lasach, 9, $38-48$. 
Borecki, T., Miścicki, S., Nowakowska, J. 1991. Problemy oceny stanu zdrowotnego lasu w inwentaryzacji okresowej. Sylwan, 4/6, 27-33.

Dmyterko, E. 1992. Struktura uszkodzenia drzewostanów na podstawie wielkoobszarowej inwentaryzacji stanu uszkodzenia lasu w 1991 roku. Notatnik Naukowy IBL, 9.

Gierczyk, B., Szczepkowski, A., Kujawa, A., Ślusarczyk, A., Zaniewski, P. 2017. Contribution to the knowledge of fungi of the Kampinos National Park (Poland) with particular emphasis on the species occurring in burnt places. Acta Mycologica, 52 (1), 1093. https://doi.org/10.5586/am.1093.

Głowacki, Z., Ferchmin, M. 2003. Chronione, rzadkie i zagrożone gatunki roślin naczyniowych Kampinoskiego Parku Narodowego i jego otuliny. In: Kampinoski Park Narodowy. Przyroda Kampinoskiego Parku Narodowego. Volume I (ed.: R. Andrzejewski). Kampinoski Park Narodowy, Izabelin, 259-274.

Heymanowski, K. 1969a. Budnicy i „Holendrzy” w dziejach gospodarstwa leśnego na Mazowszu. Sylwan, 5, 21-40.

Heymanowski, K. 1969b. Rozwój sieci osadniczej w dobrach kampinoskich od połowy XV do połowy XIX wieku. Kwartalnik Historii Kultury Materialnej, 17 (2), 417-429.

Jaszczak, R. 1995. Zmiana stanu zdrowotnego drzewostanów sosnowych pod wpływem średnich skażeń $\mathrm{z}$ uprzemysłowionej aglomeracji miejskiej. Sylwan, 8, 43-49.

Jaszczak, R. 1999. Monitoring lasów. Wyd. AR, Poznań.

Jaworski, A. 2004. Podstawy przyrostowe i ekologiczne odnawiania oraz pielęgnacji drzewostanów. PWRiL, Warszawa.

Karasiński, D., Kujawa, A., Gierczyk, B., Ślusarczyk, T., Szczepkowski, A. 2015. Grzyby wielkoowocnikowe Kampinoskiego Parku Narodowego. Kampinoski National Park Publishing House, Izabelin.

Lech, P. 1995a. Monitoring stanu zdrowotnego lasów w USA cele i metody. Las Polski, 2, 18-19.

Lech, P. 1995b. Przydatność szacunkowej metody określania defoliacji drzew do badań stanu zdrowotnego lasu. Sylwan, 8, 99-107.

Lehner, B., Doll, P., Alcamo, J., Henrischs, T., Kaspar, F. 2006. Estimating the impact of global change on flood and drought risk in Europe: a continental, integrated analysis. Climatic Change, 75, 273-299.

Mańka, K. 2005. Fitopatologia leśna. PWRiL, Warszawa.

Marczak, D. 2010. Strojniś nadobny Philaeus chrysops (PODA, 1761) (Araneae: Salticidae) w Kampinoskim Parku Narodowym. Parki Narodowe i Rezerwaty Przyrody, 29 (4), 108-110.

Marczak, D., Masiarz, J. 2013. Rzadkie gatunki chrząszczy saproksylicznych (Insecta: Coleoptera) Kampinoskiego Parku Narodowego. Parki Narodowe i Rezerwaty Przyrody, 32, 73-84.

Obmiński, Z. 1970. Zarys ekologii. In: Sosna zwyczajna (ed.: S. Białobok). PWN, Warszawa-Poznań, 152-231.

Pepłowska-Marczak, D. 2018. Description and characteristic of bird species inhabiting dry coniferous forests exceeding 150 years of age in Kampinos National Park. World Scientific News, 92 (2), 155-170.

Przybylski, T. 1993. Ekologia. Autekologia i synekologia. In: Biologia sosny zwyczajnej (eds.: S. Białobok, A. Boratyński, W. Bugała). Sorus Publishing House, Poznań-Kórnik.

Sierota, Z. 1995. Przerzedzenie koron drzew jako efekt stresu i źródło stresu. Sylwan, 8, 5-24.

Szczygielski, M. 2002. Operat ochrony ekosystemów leśnych na okres 01.01.2002 r. - 31.12.2021 r. Volume I. Biuro Urządzania Lasu I Geodezji Leśnej, Warszawa.

Szymański, S. 2001. Ekologiczne Podstawy Hodowli Lasu. Poradnik Leśniczego. PWRiL, Warszawa.

Tucker, S.A., Nebeker, T.E., Warriner, M.D., Jones, W.D., Beatty, T.K. 2004. Effects of artificial defoliation on the growth of cottonwood: simulation of cottonwood leaf beetle defoliation. In: Proceedings of the $12^{\text {th }}$ biennial southern silvicultural research conference (ed.: K.F. Connor). Gen. Tech. Rep. SRS-71, Asheville, NC: U.S. Department of Agriculture, Forest Service, Southern Research Station, 169-171.

Tyburski, Ł. 2015. Zróżnicowanie faz rozwojowych drzewostanów w Kampinoskim Parku Narodowym. In: Lasy w parkach narodowych i rezerwatach przyrody (eds.: D. Marczak, Ł. Tyburski), 185-191.

Tyburski, Ł., Przybylski, P. 2016. Health condition of the Scots pine (Pinus sylvestris) in Kampinos Na- 
tional Park - preliminary studies. Folia Forestalia Polonica, Ser. A - Forestry, 58 (4), 240-245.

Wawrzoniak, J. (ed.) 2015. Stan uszkodzenia lasów w Polsce w 2014 roku na podstawie badań monitoringowych. IBL, Sękocin Stary.

Zgorzelski, M, Pawłowska, T. 2003. Geomorfologia. In: Kampinoski Park Narodowy. Przyroda Kampino- skiego Parku Narodowego. Volume I (ed.: R. Andrzejewski). Kampinoski National Park Publishing House, Izabelin, 87-95.

Zielony, R. 2004. Zarys dziejów gospodarki leśnej w Puszczy Kampinoskiej. In: Kampinoski Park Narodowy. Volume II (ed.: R. Andrzejewski). Izabelin, 87-109. 